\title{
Recommendations in covid-19 times: a view for home care
}

\author{
Recomendações em tempos de COVID-19: um olhar para o cuidado domiciliar \\ Recomendaciones en tiempos de COVID-19: una mirada a la atención domiciliaria
}

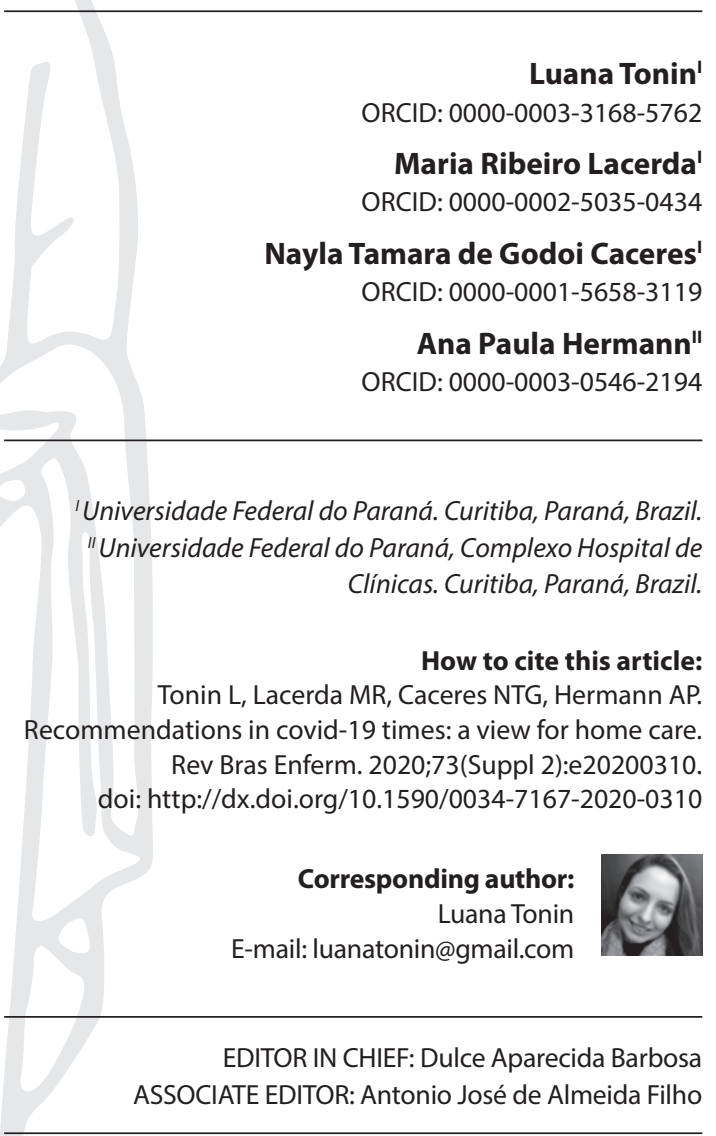

Submission: $04-18-2020$

Approval: $04-21-2020$

\begin{abstract}
Objective: To suggest recommendations for the practice of Home Nursing in the context of COVID-19. Method: Reflective study, originated from readings associated with the theme, available in current guidelines from the Pan American Health Organization, World Health Organization and the Ministry of Health. Results: Recommendations were developed from current scientific evidence for prevention of infections, control of epidemics and pandemics in the Brazilian home scenario. Final considerations: the reflections achieved contribute to guiding actions for better assistance to the patient, family caregivers and the community in the perspective of safe home care with COVID-19, and it is characterized as an introductory discussion on the theme, encouraging new studies to be carried out from the unfolding of the current scenario.

Descriptors: SARS Virus; Homebound Persons; Home Health Nursing; Home Care Services; Delivery of Health Care.
\end{abstract}

\section{RESUMO}

Objetivo: Propor recomendações para a prática de enfermagem domiciliar no contexto da COVID-19. Método: Estudo reflexivo, produzido com base em leituras correlacionadas com a área temática, disponíveis em diretrizes atuais da Organização Pan-Americana da Saúde, Organização Mundial da Saúde e Ministério da Saúde. Resultados: Foram construídas recomendações segundo evidências científicas atuais para prevenção de infecções, controle de epidemias e pandemias no contexto domiciliar brasileiro. Considerações finais: As reflexões realizadas contribuem para nortear ações com vistas a uma melhor assistência ao paciente, familiares cuidadores e comunidade na perspectiva de um cuidado domiciliar seguro em relação à COVID-19; se caracterizam como uma discussão inicial sobre o tema, estimulando que novos estudos sejam realizados com base na evolução do cenário atual.

Descritores: Vírus da SARS; Pacientes Domiciliares; Enfermagem Domiciliar; Serviços de Assistência Domiciliar; Assistência à Saúde.

\section{RESUMEN}

Objetivo: Proponer recomendaciones para la práctica de enfermería domiciliaria en el contexto de la COVID-19. Método: Estudio reflexivo, producido a partir de lecturas relacionadas con el área temática, disponibles en directrices actuales de la Organización Panamericana de la Salud, Organización Mundial de la Salud y Ministerio de la Salud. Resultados: Han sido construidas recomendaciones a partir de evidencias científicas actuales para prevención de infecciones, control de epidemias y pandemias en el contexto domiciliario brasileño. Conclusiones: Las reflexiones realizadas contribuyen para orientar acciones con vistas a una mejor asistencia al paciente, familiares cuidadores y comunidad en la perspectiva de una atención domiciliaria segura en relación a la COVID-19; se caracterizan como una discusión inicial sobre el tema, estimulando que nuevos estudios sean realizados a partir de la evolución del escenario actual. Descriptores: Virus del SARS; Pacientes Domiciliares; Enfermería Domiciliar; Servicios de Asistencia Domiciliaria; Asistencia a la Salud. 


\section{INTRODUCTION}

At the end of December 2019, the first cases of the disease called COVID-19, caused by the SARS-CoV-2 virus, were recorded in Wuhan province, China ${ }^{(1)}$, from that moment the numbers of infected people increased and spread to all continents, but only on March $11^{\text {th }}, 2020$, COVID-19 was defined by the World Health Organization (WHO) as a pandemic ${ }^{(2)}$.

Since then, health institutions around the world and nursing services have been under continuous pressure against a potentially fatal respiratory disease, but it is still uncertain, as so far there is no specific vaccine or treatment against the virus, so quarantine and social isolation have been the measure taken by several countries in an attempt to reduce transmission ${ }^{(2)}$.

The role of nurses and other professionals goes beyond hospital environments, many of them work in the homes of patients, and in this health scenario, home patients are usually those with acute, chronic, unstable, in palliative care, with respiratory syndromes, neurological, hypertensive, diabetic disorders, and are also susceptible to the SARS-CoV-2 virus(3).

Home care stands out from the technical-scientific knowledge learned during the training of nursing professionals, as entering someone's home and developing care actions requires much more than knowing and acting. Because care is carried out in at the patient and his family's environment, and the health professional is a mere guest ${ }^{(4)}$.

The home is the place of care, it is in this environment that relationships are built and strengthened, beliefs, values, habits and traditions are considered and discussed in the planning of actions, as the home scenario influences and affects the recovery and health of the patient ${ }^{(4)}$.

The care provided by nurses at home, even if considered relevant, is still incipient given the specificity of the current scenario. It is considered that studies addressing the theme of COVID-19 at home can be identified ${ }^{(3,5)}$. However, currently, there are no specific norms, policies, or scientific consensus on the description and recommendation of nursing care at home for COVID-19, thus showing a knowledge gap.

In this perspective, this theoretical-reflective essay was developed from readings associated with the theme, having as the main sources materials produced by the World Health Organization, Pan American Health Organization, and Ministry of Health. These documents were developed from previous and current guidelines with the best scientific evidence for preventing infections, controlling epidemics and pandemics.

\section{OBJECTIVE}

To suggest recommendations for the practice of Home Nursing in the context of COVID-19.

\section{Home nursing practice and COVID-19}

The WHO recommends that all people suspected of having COVID-19 with severe acute respiratory infection be screened at the first contact with the health system and that emergency treatment be started based on the severity of the disease. It also recommended that all cases confirmed in the laboratory be isolated and treated in a health facility ${ }^{(3,5)}$.

The WHO, later, updated the treatment guidelines for patients with Acute Respiratory Infection associated with the SARS-CoV-2 virus including guidelines for vulnerable populations (for example, the elderly, pregnant women and children). In occasions where isolation in a health facility from all cases is not possible, WHO emphasizes prioritizing those most likely to have poor results: patients with severe and critical illnesses and those with mild illness and risk of poor outcome (age > 60 years, cases with comorbidities, for example, chronic cardiovascular disease, chronic respiratory disease, diabetes, cancer) $)^{(5-6)}$.

If all mild cases cannot be isolated in health institutions, those with mild illness and without risk factors may be isolated in nontraditional units, such as reused hotels, stadiums or gyms, where they can remain until symptoms disappear and laboratory tests for the COVID-19 virus are negative. Alternatively, patients with mild illness and without risk factors can be managed at home ${ }^{(3,5-6)}$.

For those with mild illness, hospitalization may not be necessary or may not be possible due to the overcrowded health system, unless there is concern about the fast worsening of the condition ${ }^{(6)}$. Thus, if there are patients with mild illness, the care at home can be considered, as long as they can be followed-up and treated by family members and health professionals respectively ${ }^{(3)}$.

Home care can also be considered when hospital care is not available or is unsafe (for example, size is limited and resources are unable to meet the demand for health services). In any of these situations, patients with mild symptoms ${ }^{(3)}$ and without chronic conditions, such as: pulmonary or heart disease, kidney failure or immunocompromised conditions that subject the patient at increased risk of developing complications, can be treated at home. This decision requires careful clinical judgment by the multi-professional team and must involve an assessment of the safety of the patient's home environment for continuity of care ${ }^{(5)}$.

\section{Recommendation for home nursing care in cases of COVID-19}

In cases where care should be provided at home, if possible, the nurse should assess to check if the home environment is adequate for the continuity of care; the health professional should assess whether the patient and family can adhere to the recommended precautions as part of the isolation of home care (for example, hand hygiene, respiratory hygiene, cleanliness of the environment, movement limitations around or at home) and if safety issues can be addressed (for example, accidental ingestion and fire risks associated with the use of alcohol-based friction) $)^{(3,5)}$.

If and whenever possible, a communication link with the nurse or the health team, or both, must be established during the period of home care, that is, until the patient's symptoms have completely disappeared ${ }^{(3)}$. But comprehensive information about COVID-19 and its transmission is needed to define the length of isolation precautions at home. Patients and family members should be informed about personal hygiene, basic prevention and infection control measures so that they can care as safely as possible for the person suspected of having COVID-19 to prevent the infection from spreading to family contacts ${ }^{(3,5)}$. The patient and family members should receive ongoing support and education, and monitoring should continue during home 
care. Nurses should guide patients and family members to follow the recommendations explained in Charts 1 and 2 respectively.

The nurse, when preparing for home care, must select the necessary materials, must carry out a risk assessment to choose the appropriate personal protective equipment, and in this case follow the recommendations for contact precautions and droplets, and others as explained in Chart 3.

Chart 1- Recommendations for the patients

\section{Recommendations for the patients*}

- Stay alone in a well-ventilated room (that is, with open windows and an open door).

- Avoid sharing spaces, if necessary, do this at separate times from other residents of the house.

- Do not take in visitors until your complete recovery and the signs or symptoms of COVID-19 disappear.

- Wash hands frequently and also before eating, after using the bathroom and whenever your hands look dirty, using soap and water. If your hands are not visibly dirty, you can rub them with $70 \%$ alcohol hand sanitizer.

- Use disposable paper towels to dry your hands after washing them with soap and water. If they are not available, use clean cloth towels and replace them frequently.

- Use a surgical mask to hold back respiratory secretions $s^{(7)}$ and you should change it whenever it is wet, avoiding handling it.

- Perform severe nose/nostrils hygiene when you do not tolerate a surgical mask, that is, cover your mouth and nose with a disposable tissue when coughing or sneezing, then discarding them and washing your hands. If you use cloth tissues, wash them with soap and water.

- Clean and sanitize surfaces that are frequently touched such as bedside tables, bed frames and other bedroom and bathroom furniture daily, when in private use. First, use common soap or detergent and, after rinsing, apply a common disinfectant containing $0.1 \%$ sodium hypochlorite (for example, equivalent to $1000 \mathrm{ppm})^{(3)}$.

- Keep a covered trash can in the room with a plastic bag on top of it.

- Place contaminated clothing in a laundry bag ${ }^{(3)}$.

- Stay away from vulnerable people, the elderly and immunosuppressed people.

- Pay attention to the symptoms and if you feel a worsening request a reassessment.

Note: * If the patient is unable to perform the tasks mentioned above, assistance from a family caregiver is necessary.

Chart 2 - Recommendations for family caregivers

\section{Recommendations for family caregivers}

- Minimize sharing spaces. Family members must stay in a different room or, if this is not possible, keep a distance of at least 1 meter from the sick person (for example, sleeping in a separate bed) ${ }^{(6)}$.

- Keep sharing spaces (for example, kitchen, bathroom) well ventilated (with windows open).

- Reduce the number of caregivers. Preferably, designate a person who is in good health and who does not have chronic conditions or is immunocompromised ${ }^{(6)}$

- Wash hands after any type of contact with patients or their close environment ${ }^{(7)}$, and also before and after preparing food, before eating, after using the bathroom and whenever your hands look dirty, using soap and water. If hands are not visibly dirty, $70 \%$ alcohol-based rubbing can be used.

- Use disposable paper towels to dry your hands after washing them with soap and water. If they are not available, use clean cloth towels and replace them frequently.
Chart 2 (concluded)

\section{Recommendations for family caregivers}

- Clean and sanitize the bathroom surfaces at least once a day. First, use common soap or detergent and, after rinsing, apply a common disinfectant containing a $0.1 \%$ sodium hypochlorite (for example equivalent to $1000 \mathrm{ppm})^{(3)}$.

- Utensils used by the patient must be washed with water and common detergent after use, and they can be reused (preferably by the patient) instead of being discarded ${ }^{(3)}$.

- Wash beddings in the machine/tank with regular washing powder, hot water, between $60-90^{\circ} \mathrm{C}\left(140-194^{\circ} \mathrm{F}\right)$ and dry them thoroughly ${ }^{(3)}$.

- Do not shake dirty clothing and prevent contact of contaminated materials with the skin and clothing you are using ${ }^{(3)}$.

- Protective gloves and clothing (for example, plastic aprons) should be used when cleaning surfaces or when handling clothes or sheets soiled with body fluids ${ }^{(3)}$.

- Depending on the context, rubber (reusable) or disposable gloves can be used. After use, rubber gloves should be cleaned with soap and water and decontaminated with $0.1 \%$ sodium hypochlorite solution.

Disposable gloves must be discarded after each use.

- Wash hands before putting on and after removing gloves ${ }^{(3)}$.

- Avoid other types of exposure to contaminated items in the patient's close environment (for example, do not share toothbrushes, cigarettes, kitchen utensils, plates, drinks, towels, clothes or bedding).

- Gloves, masks and other waste generated during home care should be placed in a trash can with a lid in the patient's room before disposing of it as infectious waste ${ }^{(8)}$.

- Disposal of infectious waste must be provided for and provided by the local health authorities (specialized staff) ${ }^{(3)}$.

- In places where there is no specialized team, identification of the contaminated material should be done for the management of the selective collection team.

Chart 3 - Recommendations for Nurses in home care

\section{Recommendations for Nurses in home care}

- Wear a surgical mask that covers your mouth and nose when you are in the same room as the patient. Masks must not be touched or handled during use ${ }^{(3)}$.

- Replace the mask immediately if it gets wet or dirty ${ }^{(3)}$.

- Remove the mask using the appropriate technique - that is, do not touch the front, but untie it.

- Discard the mask immediately after use and wash hands.

- Wear gloves and a disposable N95 mask when providing mouth or respiratory care and handling feces, urine and other waste.

- Wash hands before and after removing gloves and masks.

- Do not reuse masks or gloves.

- Disposal of materials must be provided for and provided by the local health authorities (specialized staff) ${ }^{(8)}$.

- In places where there is no specialized team, identification of the contaminated material should be done for the management of the selective collection team.

- Perform, when indicated and possible, the collection of diagnostic tests before releasing patients from home isolation.

- Establish communication with the patient and family caregiver during the observation period.

- Supervise the health of others living in the same house by calling them regularly, but best and if possible, through daily home visits, so that specific diagnostic tests can be performed as needed ${ }^{(9)}$.

- Keep an eye on compliance with home isolation by the patient and others living in the same house, clarifying them about the importance of this measure. 
Chart 3 (concluded)

\section{Recommendations for Nurses in home care}

- Give psychological support to the patient and family members and call on psychology professionals when necessary.

- Inform the people living in the same house in advance about when and where to seek care, if they become ill, the most appropriate transport to use, when and where to go for the designated health facility and what precautions should be followed ${ }^{(9)}$.

- Inform the patient and family about possible signs of worsening of the clinical condition and conduct to be followed.

- Record all information in the patient's medical record, remembering that paper records should be avoided and electronic devices used for registration purposes and should be disinfected after use.

\section{FINAL CONSIDERATIONS}

This reflection aimed to suggest recommendations based on recent evidence to guide nurses work in home care with prevention and infection control in confirmed or suspected patients with COVID-19.
It is hoped that these guidelines will promote practical strategies for home nursing care with people and communities, aiming to expand the engagement and attitude in the search for better resolution of cases and situations of health risk in their real and potential scenarios.

It is believed that the recommendations now made can contribute to the expansion of discussions on home nursing care in the context of COVID-19, also, to guide actions to improve care about the safe care of the patient, family and territory.

Thus, this study is characterized as an initial step in the discussion of home care and COVID-19, it may offer subsidies for new reflections that promote and better elucidate the contributions of nursing from the advance in the world and Brazilian scenario, contributing to teaching and research.

As a limitation, these guidelines involve the need to adapt the political, social and professional structures, so that the professional can exercise, incorporate and implement such practices.

\section{REFERENCES}

1. Ministério da Saúde (BR). O que é coronavírus? [Internet]. Brasília (DF): Ministério da Saúde; 2020 [cited 2020 Apr 05]. Available from: https:// www.saude.gov.br/o-ministro/746-saude-de-a-a-z/46490-novo-coronavirus-o-que-e-causas-sintomas-tratamento-e-prevencao-3

2. Organização Pan-Americana da Saúde (BR). Folha informativa - COVID-19 (doença causada pelo novo coronavírus) [Internet]. Brasília (DF): OPAS; 2020 [cited 2020 Apr 05]. Available from: https://www.paho.org/bra/index.php?option=com_content\&view=article\&id=6101:covid19\&ltemid=875

3. World Health Organization. Home care for patients with COVID-19 presenting with mild symptoms and management of their contacts: Interim guidance, 17 March 2020 [Internet]. Geneva:World Health Organization; 2020 [cited 2020 Mar 26]. Available from: https://www.who.int/publicationsdetail/home-care-for-patients-with-suspected-novel-coronavirus-(ncov)-infection-presenting-with-mild-symptoms-and-management-of-contacts

4. Lacerda MR. Brevidades sobre o cuidado domiciliar. Rev Enferm UFSM [Internet]. 2015 [cited 2020 Apr 15];5(2):1-2. Available from: https:// periodicos.ufsm.br/reufsm/article/view/18657/pdf

5. World Health Organization. Home care for patients with Middle East respiratory syndrome coronavirus (MERS-CoV) infection presenting with mild symptoms and management of contacts: interim guidance [Internet]. Geneva: World Health Organization; 2018 [cited 2020 Jan 26]. Available from: https://apps.who.int/iris/handle/10665/272948

6. World Health Organization. Infection prevention and control of epidemic- and pandemic-prone acute respiratory diseases in health care [Internet]. Geneva: World Health Organization; 2014 [cited 2020 Jan 26]. Available from: https://www.who.int/csr/bioriskreduction/ infection_control/publication/en/

7. World Health Organization. Clinical management of severe acute respiratory infection (SARI) when COVID-19 disease is suspected: Interim guidance, 13 March 2020 [Internet]. Geneva:World Health Organization; 2020 [cited 2020 Mar 17]. Available from: https://www.who.int/ publications-detail/clinical-management-of-severe-acute-respiratory-infection-when-novel-coronavirus-(ncov)-infection-is-suspected

8. World Health Organization. WHO guidelines on hand hygiene in health care: first global patient safety challenge [Internet]. Geneva: World Health Organization; 2009[cited 2020 Jan 20]. Available from: https://www.who.int/gpsc/5may/tools/who_guidelines-handhygiene_ summary.pdf

9. World Health Organization. Global surveillance for human infection with novel coronavirus (2019-nCoV): interim guidance, 31 January 2020 [Internet]. Geneva: World Health Organization; 2020[cited 2020 Mar 17]. Available from: https://apps.who.int/iris/handle/10665/330857 